\title{
The Modification of Hion Hopscotch for Developing Children's Gross Motor and Social
}

\author{
Nur Azizah Sriwidari, Mustaji, Rachma Hasibuan \\ Universitas Negeri Surabaya \\ Surabaya, Indonesia \\ azizahwidari@gmail.com
}

\begin{abstract}
Nowadays children's gross motor and social are a crucial problem to be solved including Indonesian children. The low capacity of gross motor and social will affect children's lives in the future. This research aims to determine the effect of a modified hopscotch on the development of children's gross motor and social. The data collection technique used was the observation by using rating scale instrument model, while the data were analyzed with statistical analysis Mann Whitney test. The results showed that the modified hopscotch affect children's gross motor and social development. The average value and significance level of the post-test obtained Asymp value. Sig. 2 tailed of 0.000 , less than 0.05 , so it can be concluded that there is a significant difference of post-test value between the experimental and control group.
\end{abstract}

Keywords-Hopscotch modification; Gross Motor; Social

\section{INTRODUCTION}

The process of children's growth and development is very fast if given the stimulus that suitable with their development stage. Children need stimulus in gross motor and social development which can be facilitated by playing. [1] said that early childhood is a time when children love to move, like running, climbing, jumping, moving, climbing stairs, hanging, and others. Playing is an activity loved by every early children because it is a fun activity for him/her. According to [2] playing is a natural way for children to find the environment, others, and themselves. Playing meaningfully will give satisfaction for them because they will gain new experience. The process of acquiring knowledge and experiences of children is through playing that can develop children's motor and social development aspects.

Motor learning is very important to be introduced to the children because it is very influential on their growth and development. [3] argued that the implementation of motor learning at schools, children can move from a weak condition to a strong condition, or from a powerless to an independent stage. The role of teachers is very important to develop children's motor skills because the motor development of each individual are different. For example, children with optimum gross motor skills will be easy to coordinate the movement to train the balance and flexibility of his body such as jumping, hanging, zig-zag running and walking on tiptoe. Gross motor activity in early childhood can be done through various forms of activities such as running, jumping one foot, jumping two feet, creeping under the bridge of hoops and traditional games. From these kind of activity children are expected to master the coordination with their body, such as balance, and agility. It is due to gross motor is the physical motion that requires balance and coordination between the limbs by using large muscles, or the whole body [4]. Similarly, social development needs to be stimulated from an early age through playing so that it can be optimal.

The problems that arise in one of the schools in Indonesia is the development of gross motor which is still low. The observation to 90 children in B1, B2, B3 class conducted by researchers on Thursday, November 7, 2017, on one leg jump activity resulted $64 \%$ were not able to finish the activity, 36\% were able to complete the task. Some of them still often fall when jumping with one foot with the position of the foot not in the strong looks, like his legs still up and down and fall and need more examples from the teachers. The result showed that their gross motor ability is low, since only $37 \%$ has good skill. Gross motor activity still needs stimulation so that children's development will be more optimal in the coordination of foot movements, therefore, the alternatives are using the game modifications [5].

Indonesia's Minister of Education and Culture Regulation number 146/ 2014 stated that the gross motor characteristics of children which should be performed are: a) performing coordinated body movements to train flexibility, balance, and agility; b) coordinating head-to-head-hand movement in mimicking dance or gymnastics; c) performing a physical game with rules; d) skillful in use of right and left hands; e) conducting personal hygiene activities. In this case the indicators assessed on the gross motor include jumping on one leg, jumping on two legs, bowing without falling, jumping over the box, throwing a seed bag and skillfully changing the direction of the body position through a modified hopscotch game. In addition to gross motor development that is still low, social aspects also need to be stimulated.

Human is naturally born as a social creature including children. The social development aspect is very important to be taught to the children. Each individual is unique, has a different development from each other. Sometimes the social 
development of the children is fast based on his/her age, and sometimes slow and requires an optimal stimulus. Children's social development can be seen while playing with their peers in school[6]. Social development is the acquisition of the ability to behave in accordance with social demands. Early childhood social development can arise through various forms of behavior as they begin to share with others, they begin to be comfortable with others to talk to, and they enjoy playing in peers. Robinson [7]argued that children will be more mature socially if they are able to socialize with others such as greeting friends, playing with friends, visiting neighbors home, from the interaction they will develop their dependence into independence in social children.

Children's Social development requires significant stimulation. However some problems arise from this requirement, such as in one of the schools studied, a large number of children who have not worked together when playing trumpets with their groups, many of which violate the rules of the game and are not yet sportive in racing games. Observations on Monday, November 20, 2017 on 90 children, resulted 48 children who still often fall and can not cooperate with friends. If it is implied, $53 \%$ of them have a low ability and only $47 \%$ of them has been completed the task. From these problems, the alternatives are used through the modified hopscotch game.

Playing is children's media in gaining experience through fun and meaningful ways, since it will be easier for them to remember it all. Playing acts as a director of spontaneous activity (Latif, 2013: 77). Where children will practice to interact with others, the objects around them through the playful game. Similarly, in developing the low gross motor, social aspects will be optimized through the modified hopscotch game.

In order to enhance children's social development to be more optimal, it is necessary to set the indicators developed to be examined such as sportsmanship play, orderly in accordance with the group, able to make decisions toward the rules of the game, and rewards for those who complete the game independently. The indicator reference is found in the Regulation of Indonesia's Minister of Education and Culture number 146/2014 in which characteristics of children's social development include: able to play with peers, children can know the feelings of their friends and respond appropriately, show sportsmanship, share with others, understand the rules of play when playing, cooperate with friends. Based on the existing problems, modified hopscotch will be used as the treatment in developing gross motor and social, this game uses a media made of banner material with a size of 3 meters $x 1$ meter with bright colors and foot pictures as a sign for jumping at the box, while gas (throwing tool) used in the form of seed bags containing rice and corn that have been modified as a medium of the game, and the games instruction was included.

[8] revealed that motor development is a sequence of children learning that focuses on body movement, where the movement of the body plays an important role for their life. Especially, when it is related to behavior and social life so that they will have no problem with social life. It also necessary for the teacher to monitor their early rough motor development and social at school.

The game modification is required based on its usefulness, the modification is a change from the old stagee into a new stage that can change shape, function, mode of use and benefits without completely eliminating the original characteristics. Modifications to this study focused on game tools and the rules of the game. The game's steps in this study include throwing a bag of seeds into the box, jumping one foot, jumping two feet on a two-legged image, jumping over a seed bag, bending over, turning around without falling. According to Keen Achroni (2012: 52) the steps of hopscotch game include: (1) the player throws game's pawn into the plot, the pawn should not exceed the line of the box or plots, (2) players jumping from one plot to the other plot using one same leg (3) the box contained in the pawn shall not be trodden by any player .

This fascinating theory matched with [9] that stated about an attractive design of games can tickle the intellectual child, make children interact one another, satisfy the content, aesthetics, and value that exist in the product. This product is an interesting game design and its bright colors will stimulate children to immediately complete the game enthusiastically because it is done in groups so that children can compete with each other. It is very important for the teacher to know the value contained in this game. The problem-solving can be transferred in overcoming the problems in real life Sutton \& Smith [10]

\section{RESEARCH METHODS}

This research was conducted using an experimental research design type alongside a quantitative approach. Cresswel (2008: 60) stated that:" Experimental designs (also called intervention studies or group comparison studies) are procedures in quantitative research in which investigators determine whether an activity or materials make a difference in results for participants'

The reason why the researcher chose a quantitative approach was to test a hypothesis of the relationship between research variables. The design of independent variable relation with dependent variable between modified hopscotch toward children's gross motor and social development.

The design of this research used pre-test post-test design of Equivalent Group Design, in this study the control and experimental group will be given a pre-test to know the their early ability. After that, the experimental group will be given treatment by using a modified hopscotch game, while the control group is treated by using other media. The results of this treatment can be known more accurately because it can compare with the condition before treatment. (Sugiyono, 2016: 74). The design of this research can be described as follows:

\begin{tabular}{|c|c|c|c|}
\multicolumn{4}{c}{ TABLE I. RESEARCH DESIGN TABLE } \\
\hline Group & Pre-test & Treatment & Post-test \\
\hline Experiment & O1 & $X$ & O2 \\
\hline Control & O3 & - & O4 \\
\hline
\end{tabular}

Information:

O1: Initial observation result ( pre-test ) experiment group

O2: Result of final observation ( post-test ) experiment group

O3: Initial observation results ( pre-test) control group

O4: The result of the final observation ( post-test) of the control group

$\mathrm{X}$ : The experimental group was given traditional hopscotch game treatment

- : Control Group 
Explanation of the design above is before the treatment begins, both experimental and control groups are given pretest to measure the child's initial condition (O1 and $\mathrm{O} 3)$, then the experimental group is given treatment $(\mathrm{X})$ and the control group is treated with other media. After treatment was completed, both groups were equally given post-test $(\mathrm{O} 2$ and O4). With the above design, it can be seen that the effectiveness of treatment is shown by the difference between (O1 and $\mathrm{O} 2)$ in the experimental group with (O3 and $\mathrm{O} 4)$ in the control group.

A population is a group of individuals who share the same characteristics [11]. whereas the sample is a subgroup of target populations that the researcher intends to examine in order to make generalizations against the target population [11]. The samples selected were 60 children divided into two classes, namely control and experiment class, control class consisted of 30 children and experiment class of 30 children.

TABLE II. RESEARCH POPULATION

\begin{tabular}{|l|c|c|c|c|}
\hline \multirow{2}{*}{ No } & \multirow{2}{*}{ Class } & \multicolumn{3}{|c|}{ Number of children } \\
\cline { 3 - 5 } & & Boys & Girls & Total \\
\cline { 3 - 5 } & & 18 & 12 & 30 \\
\hline 1 & Class B1 & 12 & 18 & 30 \\
\hline 2. & Class B2 & 17 & 13 & 30 \\
\hline 3. & Class B3 & Total & $\mathbf{9 0}$ \\
\hline \multicolumn{5}{|c}{} \\
\hline
\end{tabular}

Based on the table above, the population in this research was 90 children in one school at Kindergarten At-Taqwa Surabaya.

\begin{tabular}{|c|c|c|c|}
\hline No. & Class name & Total & Group \\
\hline 1. & Class B3 & 30 & Control \\
\hline 2. & Class B2 & 30 & Experiment \\
\hline \multicolumn{2}{|r|}{ Total } & \multicolumn{2}{|c|}{60} \\
\hline
\end{tabular}

Based on the above table, the sample are 60 children that divided into two classes, namely control and experiment class, control class consist of 30 children and experimental class of 30 children.

Technique for collecting data was in the form of observation and validity of learning device. This research instrument used scale rating model 1 to 4 . The rating scale is a scale used to collect raw data in the form of numbers which then interpreted in the qualitative sense [12]. At the time of observation there will be a column of children's development assessment as follows: $\mathrm{BSB}$ is developing very well $=4$; $\mathrm{BSH}$ is developing as expected $=3$; $\mathrm{MB}$ is starting to develop $=2$; $\mathrm{BB}$ is undeveloped $=1$ (Regulation of Indonesia's Minister of Education and Culture: 2014: 19). The instrument used in this study was an observation guideline combined with a checklist $(\sqrt{ })$ in the form of gross motor and social development observation sheet.

The grid compiled in the data collection before and after doing the research is the standard level of achievement of the development of group B children that already exist in the curriculum of early childhood in Regulation of Indonesia's Minister of Education and Culture No. 137/2014. Here is a grid in this research is as follows:
TABLE IV. GRID SHEET OBSERVATION OF GROSS MOTOR IN CHILDREN GROUP B

\begin{tabular}{|c|c|c|c|}
\hline Variables & $\begin{array}{c}\text { Level } \\
\text { Achievement } \\
\text { of } \\
\text { Development }\end{array}$ & $\begin{array}{l}\text { Developed } \\
\text { indicators }\end{array}$ & Item statement \\
\hline \multirow{6}{*}{ Gross Motor } & \multirow[t]{3}{*}{$\begin{array}{l}\text { Performing a } \\
\text { coordinated } \\
\text { body movement } \\
\text { to train } \\
\text { flexibility, } \\
\text { balance, and } \\
\text { agility }\end{array}$} & $\begin{array}{l}\text { Jumping on } \\
\text { two feet }\end{array}$ & $\begin{array}{l}\text { Jumping on two feet } \\
\text { in a box marked } 2 \\
\text { right and left foot } \\
\text { side by side on the } \\
\text { banner box }\end{array}$ \\
\hline & & $\begin{array}{l}\text { Jumping on } \\
\text { one foot }\end{array}$ & $\begin{array}{l}\text { Jumping on } 1 \text { foot } \\
\text { on one-foot picture } \\
\text { in a box }\end{array}$ \\
\hline & & $\begin{array}{l}\text { Bending when } \\
\text { picking up a } \\
\text { seed bag }\end{array}$ & $\begin{array}{l}\text { bending over } \\
\text { without falling and } \\
\text { picking up a seed } \\
\text { bag }\end{array}$ \\
\hline & \multirow[t]{3}{*}{$\begin{array}{l}\text { Coordinating } \\
\text { eye-foot-hand- } \\
\text { head movement } \\
\text { in mimicking } \\
\text { dance or } \\
\text { gymnastics }\end{array}$} & $\begin{array}{l}\text { Changing the } \\
\text { direction of } \\
\text { the body } \\
\text { position } \\
\text { through jumps }\end{array}$ & $\begin{array}{l}\text { Jumping on two feet } \\
\text { together to rotate } \\
\text { the body in the } \\
\text { direction of the } 2- \\
\text { foot footage on the } \\
\text { image }\end{array}$ \\
\hline & & $\begin{array}{l}\text { Throwing see } \\
\text { d bag }\end{array}$ & $\begin{array}{l}\text { Throwing the seed } \\
\text { bag into the box } \\
1,2,3 \text { in the box (not } \\
\text { on the line) }\end{array}$ \\
\hline & & $\begin{array}{l}\text { jumping over } \\
\text { the box with } \\
\text { seed bag } \\
\text { inside of it }\end{array}$ & $\begin{array}{l}\text { Jumping over the } \\
\text { box with the seed } \\
\text { bag without falling }\end{array}$ \\
\hline
\end{tabular}

TABLE V. GRID SHEET OBSERVATION OF SOCIAL CHILDREN GROUP B

\begin{tabular}{|c|c|c|c|}
\hline Variables & $\begin{array}{c}\text { Level } \\
\text { Achievement of } \\
\text { Development }\end{array}$ & $\begin{array}{l}\text { Developed } \\
\text { indicators }\end{array}$ & Item statement \\
\hline \multirow{4}{*}{ Social } & \multirow[t]{2}{*}{$\begin{array}{l}\text { Showing } \\
\text { enthusiasm in } \\
\text { the competitive } \\
\text { game }\end{array}$} & $\begin{array}{l}\text { Get rewards for } \\
\text { children who } \\
\text { finish the game }\end{array}$ & $\begin{array}{l}\text { Distribution } \\
\text { of rewards for } \\
\text { children } \\
\text { completing the } \\
\text { game from } \\
\text { beginning to end }\end{array}$ \\
\hline & & $\begin{array}{l}\text { Sportsmanship } \\
\text { with shaking } \\
\text { hands before } \\
\text { playing and after } \\
\text { the game }\end{array}$ & $\begin{array}{l}\text { Shake hands to the } \\
\text { opponent play on } \\
\text { each group }\end{array}$ \\
\hline & \multirow[t]{2}{*}{ Obeying rules } & $\begin{array}{l}\text { Decision making } \\
\text { of the rules of the } \\
\text { game }\end{array}$ & $\begin{array}{l}\text { Can jump with } 1 \\
\text { strongest leg (both } \\
\text { right and left) } \\
\text { according to the } \\
\text { symbol on the } \\
\text { banner }\end{array}$ \\
\hline & & $\begin{array}{l}\text { Orderly match on } \\
\text { each post }\end{array}$ & $\begin{array}{l}\text { Orderly on the line } \\
\text { straightly on each } \\
\text { post }\end{array}$ \\
\hline
\end{tabular}

Data analysis performed using instrument validity test related to the instrument to be researched and can use expert opinion, normality test related data normality used in the research; homogeneity tests aim to ensure that the comparison groups are homogeneous groups. While the data analysis using nonparametric statistical analysis with Mann Whitney test. Mann Whitney test used was a data analysis using statistical analysis that aims to know the difference in the average of two different samples. While the hypothesis test in decision making 
to compare the value of $\mathrm{t}$ arithmetic and $\mathrm{t}$ table is as follows if $t$ arithmetic greater than $t$ table or significance value $<0.05$ then Ha is accepted and $\mathrm{H} 0$ is rejected. Whereas if the value of arithmetic is smaller than $t$ table then and $\mathrm{H} 0$ received or significance value $>0,05$ (Sugiyono, 2014: 258).

\section{RESULT AND DISCUSSION}

Based on the explanation of research results, data obtained from the observation of children's gross motor and social development. The traditional game of modified hopscotch as the treatment which was given by experiment group to be researched during the research process. Duration of the game is 2 hours a day.

The modified hopscotch game is a medium used in this research to the experimental groups. The media is from banner materials that are designed with different colors that appeal to children and have learning objectives that fit to the children's need. the experimental group was treated with modified hopscotch once weekly with a total of 8 times treatments. Indicators developed in gross motor skill were six, including jumping two feet, jumping one foot, bending over picking up a seed bag, throwing a seed bag, jumping over a box in which there is a seed bag, and turning the body for the purpose of developing a more optimal child's motor.

In the social development of the modified hopscotch game has 3 indicators of the children who aim to know the level of each child's development such as sportsmanship with shake hands before playing, get rewards for children who finish the game, and decision making in following the rules of the game.

TABLE VI. COMPARISON OF INITIAL OBSERVATION AND FINAL OBSERVATION IN THE EXPERIMENTAL GROUP AND CONTROL OF GROSS MOTOR DEVELOPMENT

\begin{tabular}{|c|c|c|c|}
\hline Group & $\begin{array}{c}\text { Initial } \\
\text { Observation }\end{array}$ & $\begin{array}{c}\text { Final } \\
\text { Observation }\end{array}$ & Increase \\
\hline Experiment & 11.7 & 21.67 & 9.97 \\
\hline Control & 11.7 & 17.63 & 5.97 \\
\hline
\end{tabular}

The average value during the initial observation of the experimental group was 11.7 and the average of the final observation was 21.67 so that the average increase during the initial observation to the end was 9.97. While the average value during the initial observation of the control group was 11.7 and the average of the final observation was 17.63 so that the average increase during the initial observation to the end was 5.97 .

TABLE VII. COMPARISON OF INITIAL OBSERVATION AND FINAL OBSERVATION IN THE EXPERIMENTAL GROUP AND CONTROL OF SOCIAL DEVELOPMENT

\begin{tabular}{|c|c|c|c|}
\hline Group & $\begin{array}{c}\text { Observation } \\
\text { Early }\end{array}$ & $\begin{array}{c}\text { Final } \\
\text { Observation }\end{array}$ & Increase \\
\hline Experiment & 7.56 & 14.3 & 6.74 \\
\hline Control & 7.47 & 11.97 & 4.5 \\
\hline
\end{tabular}

The average value during the initial observation of the experimental group was 7.56 and the average of the final observation was 21.67 so that the average increase during the initial observation to the end was 14.3 . While the average value during the initial observation of the control group was 7.47 and the average of the final observation was 11.97 so that the average increase during the initial observation to the end was 6.74 .
In this research, it was found that children who got the treatment was better in their gross motor and social development, as evidenced by looking at tables VI and VII on initial observation and final observation in the experimental and control groups. The importance of making development programs on the motor and social development from an early stage in a structured way through the game is one alternative to optimize children's development.

Opportunities to move freely, active and energetic as children's main activity is the purpose of this study that children's gross motor development getting optimal because they can explore all of their limbs through good movement in part of the body or the whole body. It is in accordance with theory by [13] that: outdoor playing spaces promoting lifelong patterns of outdoor behavior [13]. Outdoor games will encourage children's development to be healthy and influential in developing a lifelong behavior patterns. All done in a fun way. Children are happy to get the experience gained through things that funny for optimal growth and development, especially on the rough motor aspects. [14]suggested that playing is a very important activity for children's growth and development, especially the motor aspect.

Children are happy with new things, through playful games that make them play with others can be accommodated and can be stimulated social attitudes optimally that have not emerged through modified hopscotch like being sportive, orderly matching, able to take decisions (decision making) through the rules of the game and get rewards for those who finish the game. From some indicators developed for children will be stimulated social aspect. In accordance with the theory of [15] early childhood education based on interpersonal approaches that peer interest and enjoyment can enhance social development. Data is said to be normally distributed if the data has a level of significance above $5 \%$.

TABLE VIII. RESULT OF GROSS MOTOR NORMALITY TESTING

\begin{tabular}{|c|c|c|c|c|c|c|}
\hline \multirow{2}{*}{ Group } & \multicolumn{3}{|c|}{ Kolmogorov-Smirnov } & \multicolumn{3}{c|}{ Shapiro-Wilk } \\
\cline { 2 - 7 } & Statistic & $\mathrm{df}$ & Sig. & Statistic & $\mathrm{df}$ & Sig. \\
\hline Pretest-experiment & .190 & 30 & .007 & .939 & 30 & .083 \\
post-control & .172 & 30 & .024 & .886 & 30 & .004 \\
\hline Posttest-experiment & .226 & 30 & .000 & .879 & 30 & .003 \\
Pretest- control & .169 & 30 & .029 & .953 & 30 & .206 \\
\hline
\end{tabular}

From Table VIII, the value of Kolmogorov-Smirnov ${ }^{a}$ at the time of pre-test on the gross motor development data of experimental class is 0,005 and control class is 0,024 . The experimental group post-test is 0.000 and the control group is 0,029 . Thus, it can be concluded the significance value kolmogorov smirnov is $<0.05$, means that the data is not normally distributed.

TABLE IX. TEST RESULT OF NORMALITY OF SOCIAL DEVELOPMENT

\begin{tabular}{|c|c|c|c|c|c|c|}
\hline \multirow{2}{*}{ Group } & \multicolumn{3}{|c|}{ Kolmogorov-Smirnov } & \multicolumn{3}{c|}{ Shapiro-Wilk } \\
\cline { 2 - 7 } & Statistic & Df & Sig. & Statistic & df & Sig. \\
\hline $\begin{array}{c}\text { Pretest- } \\
\text { experiment } \\
\text { post -control }\end{array}$ & .217 & 30 & .001 & .900 & 30 & .008 \\
\hline $\begin{array}{c}\text { Posttest- } \\
\text { experiment }\end{array}$ & .204 & 30 & .003 & .875 & 30 & .002 \\
Pretest-control & .267 & 30 & .000 & .880 & 30 & .003 \\
\hline
\end{tabular}


From Table IX, the magnitude of Kolmogorov- Smirnov ${ }^{a} n$ at the time of pre-test in the social development data of the experimental class is 0.001 and the control class is 0.003 . The experimental group post-test was 0.001 and control group 0.000 . Thus, it can be concluded the significance value Kolmogorov Smirnov a is $<0.05$, means thst the data is not normally distributed.

\section{a. Test Result of Normality of Rough Motor Development}

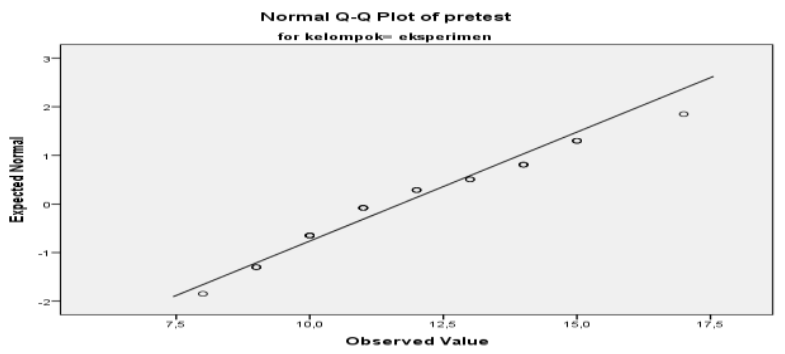

Fig. 1. Test of Normality Data of Rough Motor Development on Experiment Class (pretest)

\section{b. Test of Normality Data of Social Development}

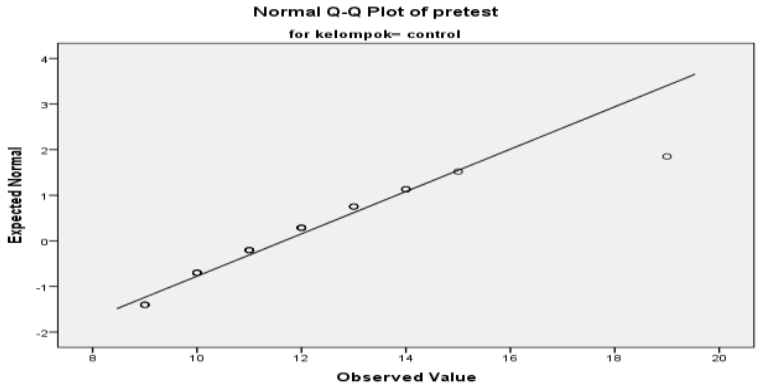

Fig. 2. Test of Normality Data of Rough Motor on Control Class (pretest)

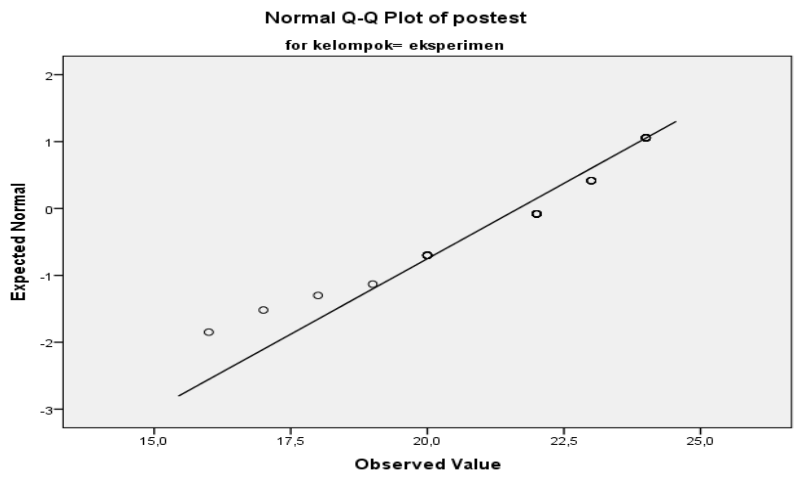

Fig.3. Test of Normality Data of Rough Motor on Control Class (pretest)

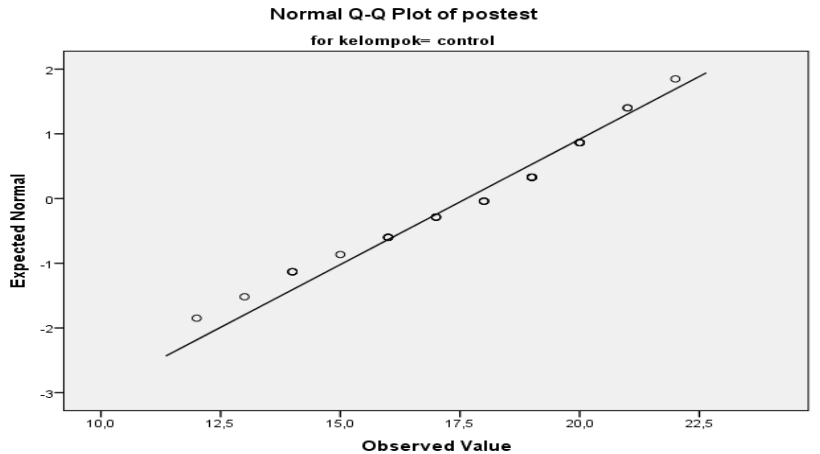

Fig. 4. Test of Normality of Rough Motor Development Data Control Class (posttest)
Figures 4.1, 4.2, 4.3 and 4.4 shows the pretest and posttest of both control and experiment classes. The data plot is away and not following the diagonal line. The distant points indicate that the data is not distributed normally. The result of Normality test can also be seen in the table below:

Homogeneity test was performed to know the value before treatment in experiment and control group. This test is guided if Levene Statistic has significance value less than 0.05 , it can be said that the variant difference between sample groups or variants between groups is not the same. On the other hand, if the value of significance greater than 0.05 then it can be said there is no difference in variants between groups is the same.

TABLE X. HOMOGENEITY TEST OF RESEARCH DATA ON GROSS MOTOR DEVELOPMENT

\begin{tabular}{|c|c|c|c|c|c|c|}
\hline \multirow{2}{*}{ Groups } & \multicolumn{3}{|c|}{ Kolmogorov-Smirnov } & \multicolumn{3}{c|}{ Shapiro-Wilk } \\
& Statistic & $\mathrm{df}$ & Sig. & Statistic & $\mathrm{df}$ & Sig. \\
\hline Pretest & .217 & 30 & .001 & .900 & 30 & .008 \\
Posttest & .204 & 30 & .003 & .875 & 30 & .002 \\
\hline
\end{tabular}

The table $\mathrm{X}$ shows that the value of Levana statistics for pre-test's results before treatment (treatment) and post-test in experimental and control groups in gross motor development is worth a significance of 0.443 and 0.284 ( $\mathrm{sig}>0.05$ ). It can be said that the variance of the two sample groups is the same or homogeneous.

TABLE XI. HOMOGENEITY TEST OF RESEARCH DATA ON SOCIAL DEVELOPMENT

\begin{tabular}{|l|l|l|l|l|}
\hline \multicolumn{1}{|c|}{ Kelompok } & Levene Statistic & df1 & df2 & Sig. \\
\hline $\begin{array}{l}\text { Pretest } \\
\text { posttest }\end{array}$ &, 198 & 1 & 58 &, 658 \\
\hline
\end{tabular}

Based on Table XI on homogeneity test of o research data on social development indicate that Levene statistic value for pre-tests result before treatment (treatment) and post-test in experiment group and control on social development have the significant value equal to 0,658 and. 0.887 ( $\mathrm{sig}>0.05$ ). It can be said that the variance of the two sample groups is the same or homogeneous.

The Mann Whitney test is part of a non-parametric statistic that aims to assist the researcher in distinguishing the group performance results contained in the sample into two groups.

TABLE XII. TEST MANN WHITNEY GROSS MOTOR DEVELOPMENT

\begin{tabular}{|c|c|c|}
\hline \multicolumn{1}{|c|}{ test } & pretest & Posttest \\
\hline Mann-Whitney U & 447.000 & 104.000 \\
Wilcoxon W & 912.000 & 569.000 \\
Z & -.045 & -5.154 \\
\hline Asymp. Sig. (2-tailed) & .964 & .000 \\
\hline
\end{tabular}

TABLE XIII. TEST MANN WHITNEY SOCIAL DEVELOPMENT

\begin{tabular}{|l|c|c|}
\hline \multicolumn{1}{|c|}{ Uji } & pretest & Posttest \\
\hline Mann-Whitney U & 422.000 & 110.500 \\
Wilcoxon W & 887.000 & 575.500 \\
Z & -.425 & -5.101 \\
\hline Asymp. Sig. & .671 & .000 \\
(2-tailed) & & \\
\hline
\end{tabular}

Table XIII shows Asymp value. Sig. (2-tailed) of 0.964 At a pre-test value of more than a significant level of 0.05 means, there is no significant difference between the both 
groups' pre-test. While at the value of post-test obtained Asymp value. Sig. (2-tailed) of 0.000 , which is less than 0.05 , it can be concluded that there are significant differences between the experimental group post-test value and control.

Based on Table 4.8 above about Mann Whitney Test on social development obtained Asymp value. Sig. (2-tailed) of 0.671 at pre-test value which is more than a significant level of 0.05 means that there is a significant difference between the experimental group pre-test value with control. While at the value of post-test obtained Asymp value. Sig. (2-tailed) of 0.000 , which is less than 0.05 , which means that there are significant differences between the experimental group posttest value and control on modified hopscotch game.

\section{CONCLUSION}

Based on the results of the research, it can be concluded that modified hopscotch crucially affects children's gross motor and social This is evidenced by the significant differences in gross motor development between the experimental and control groups, whereby gross motor development of the experimental group is better than the control group of Asymp values. Sig. (2tailed) of 0.000 , which is less than 0.05 .

Modified hopscotch significantly affects the social development of children of group B. This is evidenced by significant differences in social development between the experimental and control groups, whereby the social development of the experimental group is better than the control group of Asymp value. Sig. (2-tailed) of 0.000 less than 0.05 .

\section{Suggestion}

Based on the results of the research, presented some suggestions as follows: early childhood educators need to design a more interesting and fun game concept that can optimize the development of gross and social motor. Then, for further researchers need to modify the hopscotch to be more multi-function and can optimize other aspects that have not investigated yet.

\section{REFERENCES}

[1] C. H. Soetjiningsih, "Perkembangan anak sejak pembuahan sampai dengan kanak-kanak akhir," Jakarta Prenada Media Gr., 2012.

[2] E. Mulyasa, "Kurikulum tingkat satuan pendidikan sebuah panduan praktis," Bandung PT Remaja Rosdakarya, 2007.

[3] M. R. DiCaprio and W. F. Enneking, "Fibrous dysplasia: pathophysiology, evaluation, and treatment," $J B J S$, vol. 87, no. 8, pp. 1848-1864, 2005.

[4] R. D. Novianti, "Pengembangan media komik pembelajaran matematika untuk meningkatkan pemahaman bentuk soal cerita BAB Pecahan pada siswa kelas V SDN Ngembung,"J. Mhs. Teknol. Pendidik., vol. 1, no. 1, 2010.

[5] T. N. Postlethwaite and R. M. Thomas, Schooling in the ASEAN region: Primary and secondary education in Indonesia, Malaysia, the Philippines, Singapore, and Thailand. Elsevier, 2014.

[6] J. Hurlock and M. L. Wilson, "Searching Twitter: Separating the Tweet from the Chaff.," in Icwsm, 2011, pp. 161-168.

[7] A. Susanto, Perkembangan anak usia dini: Pengantar dari berbagai aspeknya. Kencana, 2011.

[8] G. S. Morrison, "Pendidikan anak usia dini saat ini." Yogyakarta: Pustaka Pelajar, 2016.

[9] C. Fishel, Designing for children: marketing design that speaks to kids. Rockport Publishers, 2001.

[10] R. L. Allington and P. M. Cunningham, Schools that work: Where all children read and write. ERIC, 2002.
[11] J. W. Creswell, Educational research: Planning, conducting, and evaluating quantitative. Prentice Hall Upper Saddle River, NJ, 2002.

[12] P. Sugiyono, "Dr. 2010," Metod. Penelit. Kuantitatif, Kualitatif, dan $R \& D$. Bandung CV Alf.

[13] C. W. Thompson, P. Aspinall, and A. Montarzino, "The childhood factor: Adult visits to green places and the significance of childhood experience," Environ. Behav., vol. 40, no. 1, pp. 111-143, 2008.

[14] R. Muthiah, "A Study On The Remediation Of Disorders In The Speaking Ability Of The Slow Learners In VI Standard Taught Under Activity Centred Teaching Of English," IOSR J. Res. Method Educ., vol. 4, no. 6, pp. 1-9, 2014.

[15] S. H. Petersen and D. S. Wittmer, "Kurikulum Pendidikan Anak Usia Dini Berbasis Pendekatan Antarpersonal," Jakarta Prenadamedia Gr., 2015. 